\title{
Ocular symptoms and tear film break up time (BUT) among junior high school students in Penang, Malaysia - Associations with fungal DNA in school dust
}

\author{
Dan Norbäck $^{\mathrm{a}, *}$, Jamal Hisham Hashim ${ }^{\mathrm{b}, \mathrm{c}}$, Zailina Hashim ${ }^{\mathrm{d}}$, Vinoshini Sooria ${ }^{\mathrm{e}}$, \\ Syazwan Aizat Ismail ${ }^{\mathrm{e}, \mathrm{f}}$, Gunilla Wieslander ${ }^{\mathrm{a}}$ \\ a Uppsala University, Department of Medical Science, Occupational and Environmental Medicine, University Hospital, 75185 Uppsala, Sweden \\ b United Nations University-International Institute for Global Health, 56000 Kuala Lumpur, Malaysia \\ ${ }^{c}$ Department of Community Health, National University of Malaysia, 56000 Kuala Lumpur, Malaysia \\ ${ }^{\mathrm{d}}$ Department of Environmental and Occupational Health, Faculty of Medicine and Health Sciences, Universiti Putra Malaysia, 43400 UPM, Serdang, \\ Selangor, Malaysia \\ e Department of Community Health, Faculty of Medicine and Health Sciences, Universiti Putra Malaysia, 43400 UPM, Serdang, Selangor, Malaysia \\ ${ }^{\mathrm{f}}$ Environmental Health, Allied Health Science College Sg Buloh, Ministry of Health Malaysia, 47000 Sungai Buloh; Selangor, Malaysia
}

\section{A R T I C L E I N F O}

Article history:

Received 7 December 2016

Received in revised form 29 January 2017

Accepted 30 January 2017

\section{Keywords:}

Tear film break up time (BUT)

Eye symptoms

Mould

School environment

Fungal DNA

\begin{abstract}
A B S T R A C T
Background: There are few studies on ocular effects of indoor mould exposure in schools, especially in the tropics

Objective: To study associations between eye symptoms and tear film break up time (BUT) in students and demographic data and fungal DNA in schools.

Methods: A school environment study was performed among randomly selected students in eight randomly selected secondary schools in Penang, Malaysia. Information on eye symptoms and demographic data was collected by a standardised questionnaire. BUT was measured by two methods, self-reported BUT (SBUT) and by the non-invasive Tearscope (NIBUT). Dust was collected by vacuuming in 32 classrooms and analysed for five fungal DNA sequences. Geometric mean (GM) for total fungal DNA was 7.31* $10^{4}$ target copies per gram dust and for Aspergillus/Penicillium DNA 3.34*10 4 target copies per gram dust. Linear mixed models and 3-level multiple logistic regression were applied adjusting for demographic factors.

Results: A total of 368 students (58\%) participated and $17.4 \%$ reported weekly eye symptoms the last 3 months. The median SBUT and TBUT were 15 and $12 \mathrm{~s}$, respectively. Students wearing glasses (OR $2.41, \mathrm{p}=0.01)$ and with a history of atopy $(\mathrm{OR}=2.67 ; \mathrm{p}=0.008)$ had more eye symptoms. Girls had less eye symptoms than boys $(\mathrm{OR}=0.34 ; \mathrm{p}=0.006)$ Indoor carbon dioxide in the classrooms was low (range $380-720 \mathrm{ppm}$ ), temperature was $25-30^{\circ} \mathrm{C}$ and relative air humidity $70-88 \%$. Total fungal DNA in vacuumed dust was associated with shorter SBUT ( $4 \mathrm{~s}$ shorter per $10^{5}$ target copies per gram dust; $\mathrm{p}=0.04$ ) and NIBUT ( $4 \mathrm{~s}$ shorter per $10^{5}$ target copies per gram dust; $\mathrm{p}<0.001$ ). Aspergillus/Penicillium DNA was associated with shorter NIBUT ( $5 \mathrm{~s}$ shorter per $10^{5}$ target copies per gram dust; $\mathrm{p}=0.01$ ).

Conclusion: Fungal contamination in schools in a tropical country can be a risk factor for impaired tear film stability among students.
\end{abstract}

(C) 2017 Elsevier GmbH. All rights reserved.

\section{Introduction}

The indoor environment can influence the eyes by different physiological mechanisms, including reduced stability of the

* Corresponding author at: Dept. of Medical Science, Occupational and Environmental Medicine, University Hospital, SE-751 85, Uppsala, Sweden.

E-mail address: dan.norback@medsci.uu.se (D. Norbäck).

http://dx.doi.org/10.1016/j.ijheh.2017.01.016

1438-4639/@ 2017 Elsevier GmbH. All rights reserved. lacrimal tear film, causing symptoms of eye dryness sometimes called "dry eye syndrome" (Wolkoff, 2010; Wolkoff et al., 2012). The lacrimal tear film stability can be assessed by measuring the tear film break up time (BUT). A shorter BUT is an indicator of reduced tear film stability. Previous studies have demonstrated that the lacrimal tear film can be influenced by personal factors, e.g. age, gender, use of contact lenses and eye cosmetics as well as environ-

Please cite this article in press as: Norbäck, D., et al., Ocular symptoms and tear film break up time (BUT) among junior high school students in Penang, Malaysia - Associations with fungal DNA in school dust. Int. J. Hyg. Environ. Health (2017), http://dx.doi.org/10.1016/j.ijheh.2017.01.016 
mental factors (Alves et al., 2014; Brasche et al., 2005; Wolkoff, 2010; Wolkoff et al., 2012).

Most studies on BUT are from temperate climate. One recent study concluded that low serum levels of 25-hydroxyvitamin D are associated with dry eye syndrome, indicating that there could be a latitude effect on ocular symptoms related to degree of exposure to sunshine (Yoon et al., 2016). We found only three studies on dry eye symptoms and BUT from tropical countries in Asia. One questionnaire study from Singapore found that $6.5 \%$ of the Malay adult population (age 40-80 y) had dry eye symptoms and concluded these symptoms caused reduced visual function-related quality of life (Tong et al., 2009). Two other studies measured BUT in a normal population in Malaysia. They found no gender or ethnic differences in BUT and concluded that the main determinants of reduced BUT was high age (Mohidin et al., 2002; Sharanjeet-Kaur et al., 2016).

Measurement of BUT have been used in experimental and epidemiological studies on ocular effects of indoor exposures (Norbäck and Wieslander, 2002). High room temperature and low relative air humidity (RH) can reduce BUT (Bakke et al., 2008; Wolkoff, 2010). The main focus of the indoor studies have been on ocular effects in office-like environments (Wolkoff 2008; Wolkoff et al., 2012) but some studies are available from hospitals mainly focusing on dampness and indoor mould. One study found that hospital staff in buildings with more airborne dust and presence of the mould Aspergillus fumigatus had reduced BUT (Smedbolt et al., 2001). One study found that hospital staff working in buildings with dampness in the floor construction had reduced BUT and increased prevalence of eye symptoms (Wieslander et al., 1999). One intervention study demonstrated that working in a hospital archive with previous water leakage increased eye symptoms and decreased BUT (Wieslander et al., 2007). Another intervention study found that subjects working in a habilitation center with dampness in the floor construction had increased eye symptoms (Wieslander et al., 2010).

The school environment is an important indoor environment for school children and schools can be contaminated by different pollutants such as particles, chemicals, allergens, mould and bacteria (Daisey et al., 2003; Mendell and Heath, 2005; Salo et al., 2009). We found only one study measuring effects of the school environment on BUT in school children. This intervention study found that changing the ventilation principle from mixed ventilation to displacement ventilation in the school increased BUT among students (Norbäck et al., 2011). Indoor fungal contamination can be measured by quantitative Polymerase Chain Reaction (qPCR or sometimes called real time PCR) a molecular method which can give quantitative data indoor moulds, irrespectively of viability (Haugland et al., 2004; Vesper et al., 2005). We have previously demonstrated that there is an association between latitude and the level of indoor fungal DNA and the highest levels of moulds can be found in countries near the equator (Norbäck and Cai, 2011). In a previous school environment study from Johor Bahru, Malaysia, we found associations between total fungal DNA levels in schools and eye symptoms among the students, especially for the mould Aspergillus versicolor (Norbäck et al., 2016a). Moreover there was an association between the amount of fine dust in the classrooms and eye symptoms (Norbäck et al., 2016b). However we found no previous studies on BUT among students in relation to the school environment in the tropics.

The first aim was to investigate associations between demographic data (gender, ethnicity, tobacco smoking, parental asthma/allergy, atopy, wearing glasses, contact lenses and hours of computer use) and eye symptoms and BUT among junior high school students in Penang, Malaysia. The second aim was to measure indoor climate and concentration of five sequences of fungal DNA in vacuumed dust from the students' classrooms and to study associations between these indoor factors and eye symptoms and
BUT. BUT was measured by two methods, self-reported BUT (SBUT) and by the non-invasive Tearscope (NIBUT).

\section{Material and methods}

\subsection{Study population}

The study included eight randomly selected junior high schools Penang, Malaysia. Four schools were from Penang Island and four from the mainland (Butterworth). We randomly selected four classes of grade two students in each of the eight schools, and 20 students were randomly selected from each class $(N=640)$. The study was performed in October and November 2012.

\subsection{Ethics}

The study proposal was approved by the Medical Research and Ethics Committee of the National University of Malaysia and all participants gave informed consent. The students brought the questionnaire home to answer it together with their parents or guardians, and we got signatures of approval from the students as well as from the parents. The study had permission from Penang State Health Department, the principal of each school and the head teacher of each class involved in the study.

\subsection{Assessment of demographic data and health data}

We used a self-administered questionnaire used in previous school studies in Sweden, Korea and China (Cai et al., 2011; Norbäck et al., 2016a,b; Kim et al., 2007; Mi et al., 2006; Zhao et al., 2008; Zhang et al., 2011). It contained questions on age, ethnicity, current smoking, allergies and parental allergy/asthma. There was one question on eye symptoms the last 3 months, with four alternatives (never, sometimes, weekly or daily symptoms) used in the previous school environment studies (Zhang et al., 2011; Norbäck et al., 2016a,b). The questionnaire was distributed to the pupils the same week as the technical measurements and answered at home with help of the parents. Then staff from the research team went through the questionnaires during a face-to-face interview to clarify any uncertainly in the questions. The student had no information on the results of the environmental measurements in the classrooms when they answered the questionnaires.

\subsection{Assessment of tear film break up time}

Tear film break up time was measured by two different methods (SBUT and NIBUT). Self-reported break-up time (SBUT) was assessed by recording the time the subject could keep eyes open without blinking, when watching a fixed point at the wall. This method has been previously used (Wieslander et al., 1999; Wyon and Wyon, 1987), and has been shown to correlate well with the previously used fluorescine method for measuring BUT (Wyon and Wyon, 1987). Moreover, we measured the tear film break up time by a noninvasive method (NIBUT) by ocular microscopy using a small eye microscope (Keeler TearScope; Keeler Instruments, Windsor, UK). The instrument projects a grid of equidistant circles of light on the eye surface that are blurred by tear film break up (Mengher et al., 1985). The time until the blurring of the lines can be observed is counted. The average of three tests was registered for both NIBUT and SBUT. Contact lens wearers were included.

\subsection{Assessment of exposure}

We noted details on the building construction and building materials, construction year of the building. Any signs of dampness 
or mould growth were noted. Temperature $\left({ }^{\circ} \mathrm{C}\right)$, Relative Humidity $(\mathrm{RH}, \%)$ and the concentration of $\mathrm{CO}_{2}(\mathrm{ppm})$ were measured for one hour in the classrooms during normal activities with QTrakTM IAQ monitor (TSI Incorporated, St. Paul, Minnesota, USA). The instrument logged average values over one minute and were regularly calibrated. Settled dust was collected by a $400 \mathrm{~W}$ vacuum cleaner provided with a special dust collector (ALK Abello, Copenhagen, Denmark) equipped with a Millipore filter (pore size $6 \mu \mathrm{m}$ ). The filter is made of cellulose acetate, and according to the manufacturer it retains $74 \%$ of particles $0.3-0.5 \mu \mathrm{m}, 81 \%$ of particles $0.5-1.0 \mu \mathrm{m}, 95 \%$ of particles $1-10 \mu \mathrm{m}$ and about $100 \%$ of larger particles $(>10 \mu \mathrm{m})$. Vacuuming was performed for 4 min per sample, 2 min on the floor and 2 min on other surfaces (desks, chairs) as in previous school studies (Zhao et al., 2008; Zhang et al., 2011; Norbäck et al., 2016a). Each classroom was divided into two parts, one near the corridor and the one near the windows. One dust sample was collected from each part. The dust was sieved through $0.3-\mathrm{mm}$ mesh screen to obtain the fine dust, weighted, and used for analysis of fungal DNA. The sieved dust samples were stored in a low temperature freezer $\left(-80^{\circ} \mathrm{C}\right)$.

\subsection{Analysis of fungal DNA}

Details on the analytical method for fungal DNA has been previously published (Cai et al., 2011; Norbäck and Cai, 2011). Fungal DNA was extracted from $10 \mathrm{mg}$ of sieved dust and five multiplex reactions were performed targeting the DNA of the following species: total fungi, Aspergillus spp. and Penicillium spp. (Asp/Pen), Aspergillus versicolor (A. versicolor), Stachybotrys chartarum (S. Chartarum) and Streptomyces spp. The oligonucleotides used for amplification and detection were designed using the design software Primer Express 2.0 (Applied Biosystems, Foster City, CA USA). Amplification and detection was performed on a 7300 Real-time PCR Instrument (Applied Biosystems, Foster City, CA USA) using the Taqman ${ }^{\circledR}$ Universal Master Mix (Applied Biosystems, Foster City, CA USA). The fungal DNA concentration was expressed as target copies per gram dust.

\subsection{Statistical methods}

Associations between demographic data and weekly eye symptoms were examined by multi-level multiple logistic regression, keeping sex, ethnicity, smoking, parental asthma/allergy, a history of atopy, wearing glasses, contact lenses, use of eye cosmetics and number of hours per day using computers in the models (nine covariates). The prevalence of weekly eye symptoms was calculated by coding the never or sometimes as " 0 " and weekly or daily as "1". Three levels were used, individual level, classroom level and school level. As the next step we analysed associations between room temperature, relative air humidity and $\mathrm{CO} 2$ concentration in the classrooms, amount of dust in the classrooms, fungal DNA in vacuumed dust and Petri dish samples and weekly eye symptoms, adjusting for the nine co-variates mentioned above. Finally, we analysed associations in mutually adjusted 3-level models with additional adjustment for two home environment factors (ETS and dampness/mould), including exposure variables that had $\mathrm{p}<0.1$ in the initial analysis. SBUT and NIBUT was analysed by linear mixed models adjusting for the same nine co-variates as in the logistic regression models. Finally, we analysed associations for SBUT and NIBUT with additional adjustment for the two home environment factors (ETS and dampness/mould), including exposure variables that had $\mathrm{p}<0.1$. Odds ratio (OR) with $95 \%$ confidence interval $(95 \%$ $\mathrm{CI}$ ) was calculated for the logistic regression analyses. Beta values with $95 \%$ CI was calculated from the linear mixed models. Statis- tics were performed with the STATA 13.0 statistical package using two-tailed tests at a 5\% significance level.

\section{Results}

\subsection{Personal characteristics and ocular health}

The participation rate in the questionnaire study was 58\%, 368 of 640 invited pupils participated. Among these, a total of 364 students performed SBUT, 363 performed NIBUT measurements and 363 answered the question on eye symptoms latest 3 months. The mean age was 14 years (range 14-16 years) and 54\% were girls. Among the respondents, $70.1 \%$ were Malay, $15.2 \%$ were Chinese and $14.7 \%$ were Indians. The prevalence of smoking was $0 \%$ among girls and $6.0 \%$ among boys (totally $2.7 \%$ smokers). Totally $8.2 \%$ reported pollen allergy, $7.9 \%$ cat allergy and 3.0\% dog allergy, and $15.5 \%$ reported either pollen, cat or pollen allergy (a history of atopy). The prevalence of weekly eye symptoms was $17.4 \%$. A total of $24.5 \%$ had a father or mother with asthma or allergic rhinitis (parental asthma/allergy). Boys had more eye symptoms $(p=0.005)$ and a higher prevalence of self- reported atopy $(\mathrm{p}=0.04)$ and were more often smokers $(p<0.001)$. Girls were more often wearing glasses $(p=0.002)$, contact lenses $(p=0.06)$ and used eye cosmetics more often $(\mathrm{p}<0.001)$ (Table 1$)$. The median value for SBUT was $15 \mathrm{~s}$ (IQR 9-28) and for NIBUT $12 \mathrm{~s}$ (IQR 9-21). There were no differences for SBUT or NIBUT between boys or girls or between those with and without a history of atopy (Table 2).

\subsection{Descriptive data on the schools and fungal DNA levels}

The schools were 2-4 storeys concrete buildings with painted indoor surfaces and the floor surface consisted of concrete without any paint or floor covering. There were no carpet, pot plant or book shelves in any classroom. None of the schools had a mechanical ventilation system or an air conditioning unit in the classrooms. All classrooms had electric fans in the ceiling and were with glass window panes on both sides that were kept open during lectures. Smoking was not allowed in the schools. The mean room temperature was $28^{\circ} \mathrm{C}$ (range of $25-30^{\circ} \mathrm{C}$ ), which was similar as the mean outdoor temperature $\left(29^{\circ} \mathrm{C}\right)$. The mean indoor relative air humidity was $79 \%$ (range of $70-88 \%$ ), similar as the mean outdoor air humidity (75\%). The mean $\mathrm{CO}_{2}$ concentration in the classrooms was $425 \mathrm{ppm}$ (range of 380-720 ppm), and 407 ppm outdoors. A total of seven classrooms (22\%) had signs of water leakage in the ceiling but none had visible indoor mould growth.

We found total fungal DNA and Asp/Pen DNA in all vacuumed dust samples. A. versicolor DNA were detected in $67 \%$ of the classrooms and Streptomyces DNA in $94 \%$ of the classrooms (Table 3). S. chartarum DNA in vacuumed dust was found in one classroom only at very low levels ( 5 target copies per mg dust) and was not further analysed in the regression models.

\subsection{Ocular health in relation to personal characteristics}

As a next step we analysed associations between demographic data and eye symptoms, SBUT and NIBUT. We used 3-level (student, classroom, school) multiple logistic regression models for eye symptoms and linear mixed models for SBUT and NIBUT. Girls had less eye symptoms $(p=0.006)$ and those with a history of atopy $(p=0.008)$ and those wearing glasses $(P=0.01)$ had more eye symptoms (Table 4). There were no significant associations between SBUT or NIBUT and sex, ethnicity, smoking, a history of atopy, parental asthma/allergy wearing glasses, contact lenses, use of eye cosmetics or computer use in mutually adjusted linear mixed models. Moreover, if adding the home environment factors in the models (ETS, dampness/mould, indoor painting) there were 
Table 1

Prevalence of eye symptoms, demographic data and computer use among pupils ( $\mathrm{N}=368)$ from eight junior high schools in Penang, Malaysia.

\begin{tabular}{|c|c|c|c|c|}
\hline & Overall (N = 368) (\%) & Male $(\mathrm{N}=168)(\%)$ & Female $(\mathrm{N}=200)(\%)$ & $P$-value ${ }^{\mathrm{a}}$ \\
\hline \multicolumn{5}{|l|}{ Eye symptoms } \\
\hline Weekly eye symptoms last 3 months & 17.4 & 23.4 & 12.2 & 0.005 \\
\hline Demographic data & & & & 0.74 \\
\hline Malay & 70.1 & 71.4 & 69.0 & \\
\hline Indian & 14.7 & 13.1 & 16.0 & \\
\hline Chinese & 15.2 & 15.5 & 15.0 & \\
\hline A history of atopy & 15.5 & 19.6 & 12.0 & 0.04 \\
\hline Parental asthma/allergy & 24.5 & 20.8 & 27.5 & 0.14 \\
\hline Smoker & 2.7 & 6.0 & 0 & $<0.001$ \\
\hline Wear glasses & 28.9 & 21.0 & 35.5 & 0.002 \\
\hline Use contact lenses & 4.8 & 2.4 & 6.8 & 0.06 \\
\hline Use eye cosmetics & 24.4 & 1.2 & 43.7 & $<0.001$ \\
\hline Average computer use & & & & 0.30 \\
\hline Less than $1 \mathrm{~h}$ per day & 23.8 & 19.9 & 27.2 & \\
\hline $1 \mathrm{~h}$ per day & 20.2 & 24.1 & 16.9 & \\
\hline $2 \mathrm{~h}$ per day & 26.9 & 27.7 & 26.2 & \\
\hline $3 \mathrm{~h}$ per day & 14.1 & 14.5 & 13.8 & \\
\hline More than $3 \mathrm{~h}$ per day & 15.0 & 13.8 & 15.9 & \\
\hline \multicolumn{5}{|l|}{ Home environment } \\
\hline Environmental tobacco smoke (ETS) & 48.9 & 48.2 & 49.5 & 0.80 \\
\hline Dampness/mould last 12 months & 34.8 & 31.5 & 37.5 & 0.23 \\
\hline Indoor painting last 12 months & 42.6 & 45.1 & 40.4 & 0.37 \\
\hline
\end{tabular}

a By Chi-square test.

Table 2

Tear film breakup time (BUT) among the among students $(\mathrm{N}=368)$.

\begin{tabular}{|c|c|c|c|c|c|c|c|c|}
\hline \multirow[t]{2}{*}{ Symptoms } & \multirow[b]{2}{*}{$\mathrm{N}$} & \multicolumn{2}{|c|}{ Self-reported BUT (s) } & \multirow[t]{2}{*}{ P-value ${ }^{a}$} & \multirow[b]{2}{*}{$\mathrm{N}$} & \multicolumn{2}{|c|}{ Tear scope BUT (s) } & \multirow[t]{2}{*}{ P-value } \\
\hline & & Median & IQR & & & Median & IQR & \\
\hline Total & 364 & 14.8 & $9.1-28.4$ & & 363 & 12.2 & $8.6-21.1$ & \\
\hline Male & 167 & 14.0 & $8.6-28.3$ & 0.41 & 307 & 11.6 & $8.3-21.2$ & 0.35 \\
\hline Female & 197 & 15.1 & $9.3-29.5$ & & 57 & 13,1 & $8.9-21.1$ & \\
\hline No history of atopy & 306 & 14.5 & $9.1-28.3$ & 0.95 & 307 & 11.9 & $8.5-21.1$ & 0.53 \\
\hline A history of atopy & 57 & 15.6 & $9.2-31.4$ & & 57 & 14.0 & $9.7-19.4$ & \\
\hline No weekly eye symptoms & 297 & 14.8 & $9.1-28.4$ & 0.13 & 296 & 12.0 & $8.6-21.1$ & 0.34 \\
\hline Weekly eye symptoms & 62 & 14.0 & $9.0-26.6$ & & 62 & 13.0 & $9.2-23.6$ & \\
\hline
\end{tabular}

$\mathrm{IQR}=$ Interquartile range.

a By Mann-Whitney $U$ test.

Table 3

Concentration of fungal DNA in settled dust and Petr dish samples from classrooms $(\mathrm{N}=32)$ in junior high schools in Penang, Malaysia.

\begin{tabular}{|c|c|c|c|c|}
\hline Dust exposure at school & AM & GM & $95 \% \mathrm{CI}$ of GM & $\begin{array}{l}\text { Classrooms with levels } \\
\text { above the detection limit } \\
(\%)\end{array}$ \\
\hline $\begin{array}{l}\text { Amount of fine dust (g) } \\
\text { Fungal DNA in dust (target } \\
\text { copies per gram dust) }\end{array}$ & 3.76 & 3.27 & $3.10-3.45$ & 100 \\
\hline Total fungal DNA & $9.42^{*} 10^{4}$ & $7.32^{*} 10^{4}$ & $6.79-7.89 * 10^{4}$ & 100 \\
\hline Asp/Pen DNA & $4.61^{*} 10^{4}$ & $3.34^{*} 10^{4}$ & $3.08-3.63 * 10^{4}$ & 100 \\
\hline A. Versicolor DNA & 65 & 15 & NA & 67 \\
\hline Streptomyces DNA & 10 & 7 & NA & 94 \\
\hline
\end{tabular}

$\mathrm{AM}=$ arithmetic mean, $\mathrm{GM}=$ Geometric Mean, GSD = Geometric standard deviation.

Asp/Pen: Aspergillus/Penicillium, A. versicolor: Aspergillus versicolor, S. Chartarum: Stachybotrys chartarum.

no associations between the home environment and weekly eye symptoms, SBUT or NIBUT.

\subsection{Ocular health in relation to the school environment}

Concerning the associations with the school environment, we first analysed associations between room temperature, relative air humidity and $\mathrm{CO}_{2}$ levels in the classrooms and ocular health. None of these indoor climate factors were associated with weekly eye symptoms, SBUT or NIBUT $(p>0.2)$. Then we studied associ- ations between amount of fine dust in the classroom and fungal DNA in the dust and eye symptoms, SBUT and NIBUT, adjusting for the co-variates in Table 5. There was a tendency of a higher prevalence of weekly eye symptoms in relation to amount of fine dust in the classroom $(\mathrm{p}=0.08)$. Moreover, there were positive associations between the concentration of total fungal DNA in vacuumed dust and SBUT $(\mathrm{p}=0.04)$ and NIBUT $(\mathrm{p}<0.001)$ and a positive association between the concentration of Aspergillus/Penicillium DNA in dust and NIBUT $(\mathrm{p}=0.01)$. Adding home environment factors into the models did not change the results. The corre-

Please cite this article in press as: Norbäck, D., et al., Ocular symptoms and tear film break up time (BUT) among junior high school students in Penang, Malaysia - Associations with fungal DNA in school dust. Int. J. Hyg. Environ. Health (2017), http://dx.doi.org/10.1016/j.ijheh.2017.01.016 
Table 4

Associations between personal factors and eye symptoms among students from junior high schools in Penang, Malaysia and demographic data $(\mathrm{N}=368)$.

\begin{tabular}{ll}
\hline Type of factor & Weekly eye symptoms last 3 months \\
\hline Female gender & $0.34(0.16-0.73)^{* *}$ \\
Malay & 1 (ref) \\
Chinese & $0.55(0.21-1.44)$ \\
Indian & $0.64(0.24-1.67)$ \\
Current smoker & $0.67(0.13-3.50)$ \\
A history of atopy & $2.67(1.30-5.49)^{* *}$ \\
Parental asthma/allergy & $1.53(0.77-3.05)$ \\
Wearing glasses & $2.41(1.19-4.86)^{*}$ \\
Use of contact lenses & $1.23(0.27-5.61)$ \\
Use of eye cosmetics & $0.82(0.31-2.19)$ \\
Mean hours of computer use & $0.98(0.81-1.19)$ \\
\hline
\end{tabular}

Reported data are Odds Ratios (OR) with 95\% Confidence Interval (CI), including gender, ethnicity, tobacco smoking, parental asthma/allergy (heredity) and a history of atopy in the multiple logistic regression models including all factors (mutual adjustment).

Ethnicity was analysed as categorical variable with Malay race as reference category. OR with $95 \% \mathrm{CI}$ for computer use was calculated for a change of one hour of computer use.

$$
\text { * } \mathrm{p}<0.05 \text {. }
$$$$
\mathrm{p}<0.01 \text {. }
$$

lation between total fungal DNA and Aspergillus/Penicillium DNA was relatively high (Kendal Tau beta $=0.69$ ). If adding fungal DNA and Aspergillus/Penicillium DNA in the same linear mixed model, adjusting for the covariates from Table 4, the association for total fungal DNA remained significant while the association for Aspergillus/Penicillium DNA was no longer significant but the beta values of the associations remained the same as in the previous one-exposure model presented in Table 5.

\section{Discussion}

A total of $17 \%$ of the students had weekly eye symptoms and male gender, a history of atopy and wearing glasses were risk factors for eye symptoms. The concentration of total fungal DNA and Aspergillus/Penicillium DNA in vacuumed dust from the classrooms were associated with reduced tear film stability. To our knowledge, our study is the first study on associations between the school environment and ocular symptoms and tear film stability among students in a tropical country.

Particles in indoor environments can be sampled by different methods, sampling different size fractions and different locations in the room. We sampled dust by vacuuming of floors and upper horizontal surfaces (desks and chairs) in the classrooms. The advan- tage with vacuuming dust is that it samples dust from all parts of room and collects all size fractions. Moreover, the amount of collected dust is large enough to analyse different types of components in the dust. The disadvantage is that some of the collected particles are large and may not become airborne and thus not inhaled by the students.

\subsection{Descriptive data on tear film stability}

The prevalence of weekly eye symptoms was $17.4 \%$, higher than the $11.6 \%$ prevalence found in our previous school environment study in Johor Bahru, Malaysia (Norbäck et al., 2016a) and higher than the $6.5 \%$ prevalence of dry eye syndrome among adults in Singapore (Tong et al., 2009). In our study, the medians of SBUT and NIBUT were 14.8 and $12.2 \mathrm{~s}$, respectively. We found no previous studies on tear film stability among children in tropical countries. A similar mean value for NIBUT (12 s) but somewhat lower mean SBUT (11 s) was found in a Swedish study among elementary school children (Norbäck et al., 2011). The tear film stability can be influenced by different factors. A high relative air humidity can be beneficial (Wolkoff et al., 2012) but air pollutants (both fungal contamination, particles and volatile chemicals) can reduce the tear film stability. The similarity in BUT between Swedish and Malaysian students could be because the beneficial effects of high RH in Malaysia is balanced by more air pollution in the classrooms in Malaysia. The level of fungal DNA in dust is related to the latitude with much higher levels of fungal DNA in the tropics (Norbäck and Cai, 2011).

We found two studies on NIBUT in the general population in Malaysia. One small study in 48 subjects aged 7-60 years found a mean NIBUT of $15.8 \mathrm{~s}$ (Mohidin et al., 2002). Another larger study in an adult population $(\mathrm{N}=145)$ found a shorter NIBUT, with an overall median of $6.7 \mathrm{~s}$ for all ages and $8.5 \mathrm{~s}$ in the youngest ages (20-29 y) (Tong et al., 2009). Our results for NIBUT is near the average of these two studies, but is not directly comparable since the age range is not the same.

\subsection{Indoor climate and ventilation in the schools}

The room temperature (range $25-30^{\circ} \mathrm{C}$ ) and relative air humidity $(70-88 \%)$ was high and level of $\mathrm{CO}_{2}$ was low in the classrooms (range 380-690 ppm) and always below the recommended limit of 1000 ppm (ASHRAE, 1999). This was due to effective natural ventilation since all classrooms had windows with glass panes on both sides of the classrooms. We found no associations between these indoor climate factors and eye symptoms or tear film stability. One possible reason could be that there were little variation in room

Table 5

Associations between eye symptoms and tear film break-up time (BUT) among students and fungal DNA in dust and amount of fine dust in the classrooms ( $=368$ ).

\begin{tabular}{|c|c|c|c|}
\hline Type of exposures & $\begin{array}{l}\text { Weekly eye symptoms } \\
\text { last } 3 \text { months OR }(95 \% \mathrm{CI})\end{array}$ & $\begin{array}{l}\text { Self-reported BUT } \\
\text { (seconds) Beta ( } 95 \% \mathrm{CI})\end{array}$ & $\begin{array}{l}\text { Tearscope BUT } \\
\text { (seconds) Beta }(95 \% \mathrm{CI})\end{array}$ \\
\hline Asp/Pen DNA & $1.01(0.47-2.17)$ & $-3.7(-9.8$ to 2.4$)$ & $-5.1(-9.1 \text { to }-1.2)^{*}$ \\
\hline A. versicolor DNA & $0.96(0.69-1.35)$ & $-0.5(-3.1$ to 2.1$)$ & $1.1(-2.8$ to 1.5$)$ \\
\hline Streptomyces DNA & $0.88(0.62-1.26)$ & $-0.5(-2.8$ to 1.7$)$ & $0.0(-1.5$ to 1.5$)$ \\
\hline Total fungal DNA & $0.84(0.52-1.35)$ & $-4.0(-7.6 \text { to }-0.3)^{*}$ & $-4.2(-6.6 \text { to }-1.9)^{* * *}$ \\
\hline Amount of fine dust & $1.13(0.98-1.30)^{(*)}$ & $-0.1(-1.2$ to 1.1$)$ & $0.3(-0.5$ to 1.1$)$ \\
\hline
\end{tabular}

Asp/Pen: Aspergillus/Penicillium, A. versicolor: Aspergillus versicolor.

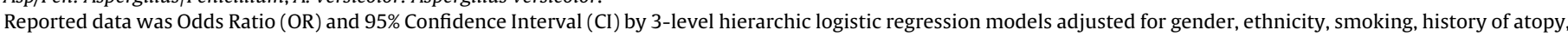
parental asthma/allergy, wearing glasses, contact lenses, eye cosmetics and hours of computer use.

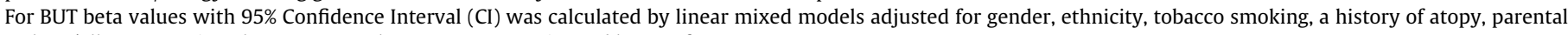
asthma/allergy, wearing glasses, contact lenses, eye cosmetics and hours of computer use.

(OR calculated for $10^{5}$ target copies per gram dust increase in total fungal DNA).

(OR calculated for $10^{5}$ target copies per gram dust increase in Asp/Pen DNA).

(OR calculated for 100 target copies per gram dust increase in A. versicolor DNA).

(OR calculated for 10 target copies per gram dust increase in Streptomyces DNA).

(OR calculated for $1000 \mathrm{mg}$ increase in fine dust).

$\left.{ }^{*}\right) \mathrm{P}<0.1$.

* $\mathrm{p}<0.05$.

**** $\mathrm{p}<0.001$

Please cite this article in press as: Norbäck, D., et al., Ocular symptoms and tear film break up time (BUT) among junior high school students in Penang, Malaysia - Associations with fungal DNA in school dust. Int. J. Hyg. Environ. Health (2017), http://dx.doi.org/10.1016/j.ijheh.2017.01.016 
temperature, $\mathrm{RH}$ or ventilation flow between the classrooms in our study

\subsection{Associations between tear film stability and fungal DNA}

We found that total fungal DNA and Aspergillus/Penicillium DNA in vacuumed dust were associated with reduced tear film stability. We found no previous study on associations between fungal DNA in indoor environments and tear film stability but in our previous school environment study from Johor Bahru, Malaysia, we found associations between total fungal DNA and Aspergillus versicolor DNA is swab samples from the classrooms and weekly eye symptoms among the students (Norbäck et al., 2016b). Some previous studies have found associations between building dampness, indoor mould and impaired ocular health. An increase of eye symptoms and reduced tear film stability have been demonstrated among hospital workers in buildings with dampness in the floor construction (Wieslander et al., 1999; Wieslander et al., 2010), a history of flooding (Wieslander et al., 2007) and with the mould Aspergillus fumigatus in the buildings (Smedbolt et al., 2001). In contrast to these studies, an experimental study exposing volunteers to emissions from mould building materials did not find any effect of the mould exposure on tear film stability (SBUT) or eye symptoms (Claeson et al., 2009).

\subsection{Strength and limitations}

One strength is that schools, classrooms and students were randomly selected from all secondary schools in one geographical area (Penang, Malaysia). Moreover, the response rate was reasonable and all samples were analysed after questionnaire data was completed and the same week as the indoor measurements. Moreover, the students did not have any information on the results of the environmental measurements when they answered the questionnaires. SBUT and NIBUT were assessed by a medical doctor without any knowledge on the answers in the questionnaire or the results of the environmental measurements. Since Penang has a similar climate all year around, ventilation flow or indoor levels of pollutants would be expected to be constant throughout the year. Thus we conclude that the study was not seriously influenced by selection or information bias. One limitation is that it is a cross-sectional study which limits the possibility to draw conclusions on causality. Another limitation is that we did not include measurements of fungal DNA in the home environment.

\section{Conclusions}

In conclusion, mould contamination in schools in a tropical country, measured as fungal DNA in school dust, can be a risk factor for impaired tear film stability among students. Further studies are needed on ocular effects of fungal contamination in indoor environments in the tropics.

\section{Funding}

This study was supported by grants from the Swedish council for Environmental and Agricultural Science and Spatial Planning (FORMAS), the Swedish Asthma and Allergy Association's Research Foundation and Swedish International Development Agency (SIDA).

All authors declare that they have no competing financial interest.

\section{References}

ASHRAE, 1999. Ventilation for Acceptable Indoor Air Quality, Standard. American Society for Heating, Refrigerating and Air Conditioning Engineers, Atlanta, GA. Alves, M., Novaes, P., Morraye Mde, A., 2014. Is dry eye an environmental disease? Arq. Bras. Oftalmol. 77, 193-200.

Bakke, J.V., Norbäck, D., Wieslander, G., Hollund, B., Florvaag, E., Haugen, E.N., Moen, B.E., 2008. Symptoms, complaints, ocular and nasal physiological signs in university staff in relation to indoor environment, temperature, and gender interactions. Indoor Air 18, 131-143.

Brasche, S., Bullinger, M., Petrovitch, A., Mayer, E., Gebhart, H., Herzog, V., Bischof, W., 2005. Self-reported eye symptoms and related diagnostic findings -comparison of risk factor profiles. Indoor Air 15 (10), 56-64.

Cai, G.H., Hashim, J.H., Hashim, Z., Ali, F., Bloom, E., Larsson, L., Lampa, E., Norbäck, D., 2011. Fungal DNA, allergens, mycotoxins and associations with asthmatic symptoms among pupils in schools from Johor Bahru, Malaysia. Pediatr. Allergy Immunol. 22, 290-297.

Claeson, A.S., Nordin, S., Sunesson, A.L., 2009. Effects on perceived air quality and symptoms of exposure to microbially produced metabolites and compounds emitted from damp building materials. Indoor Air 19, 102-112.

Daisey, J., Angell, W., Apte, M., 2003. Indoor air quality, ventilation and health symptoms in schools: an analysis of existing information. Indoor Air 13, 53-64.

Haugland, R.A., Varma, M., Wymer, L.J., Vesper, S.J., 2004. Quantitative PCR analysis of selected aspergillus, penicillium and paecilomyces species. Syst. Appl. Microbiol. 27, 198-210.

Kim, J.L., Elfman, L., Norbäck, D., 2007. Respiratory symptoms, asthma and allergen levels in schools - comparison between Korea and Sweden. Indoor Air 17, $122-129$.

Mendell, M.J., Heath, G.A., 2005. Do indoor pollutants and thermal conditions in schools influence student performance? A critical review of the literature. Indoor Air 15, 27-52.

Mengher, L.S., Bron, A.J., Tonge, S.R., Gilbert, D.J., 1985. A non-invasive instrument for clinical assessment of the pre-corneal tear film stability. Curr. Eye Res. 4, $1-7$.

Mi, Y.-H., Norbäck, D., Tao, J., Mi, Y.-L., Ferm, M., 2006. Current asthma and respiratory symptoms among pupils in Shanghai, China: influence of building ventilation, nitrogen dioxide, ozone, and formaldehyde in classrooms. Indoor Air 16, 454-464.

Mohidin, N., Bay, T.C., Yap, M., 2002. Non-invasive tear break-up time in normal Malays. Clin. Exp. Ophthalmol. 85, 37-41.

Norbäck, D., Cai, G.-H., 2011. Fungal DNA in hotel rooms in Europe and Asia associations with latitude, precipitation, building data, room characteristics and hotel ranking. J. Environ. Monit. 10, 2895-2903.

Norbäck, D., Wieslander, G., 2002. Biomarkers and chemosensory irritations. Int Arch. Occup. Environ. Health 75, 298-304.

Norbäck, D., Wieslander, G., Zhang, X., Zhao, Z., 2011. Respiratory symptoms, perceived air quality and physiological signs in elementary school pupils in relation to displacement and mixing ventilation system-an intervention study. Indoor Air 21, 427-437.

Norbäck, D., Hashim, J.H., Markowicz, P., Cai, G.H., Hashim, Z., Ali, F., Larsson, L., 2016a. Endotoxin, ergosterol, muramic acid and fungal DNA in dust from schools in Johor Bahru, Malaysia -associations with rhinitis and sick building syndrome (SBS) in junior high school students. Sci. Total Environ. 545-546, 95-103.

Norbäck, D., Hashim, J.H., Cai, G.H., Hashim, Z., Ali, F., Bloom, E., Larsson, L., 2016b. Rhinitis, throat and dermal symptoms, headache and tiredness among students in schools from Johor Bahru, Malaysia : associations with fungal DNA and mycotoxins in classroom dust. PLoS One 11, e01479976.

Salo, P.M., Sever, M.L., Zelin, D.C., 2009. Indoor allergens in school and day care environments. J. Allergy Clin. Immunol. 124, 185-192.e9.

Sharanjeet-Kaur, Ho, C.Y., Mutalib, H.A., Ghazali, A.R., 2016. The relationship between tear ferning patterns and non-invasive tear break-up time in normal asian population. J. Optom. 9, 175-181.

Smedbolt, H.T., Ahlen, C., Norbäck, D., Hilt, B., 2001. Signs of eye irritation in female hospital workers and the indoor environment. Indoor Air 11, 223-231.

Tong, L., Saw, S.M., Lamoureux, E.L., Wang, J.J., Rosman, M., Tan, D.T., Wong, T.Y., 2009. A questionnaire-based assessment of symptoms associated with tear film dysfunction and lid margin disease in an Asian population. Ophthalmic Epidemiol. 2009 (16), 31-37.

Vesper, S.J., Wymer, L.J., Meklin, T., Varma, M., Stott, R., Richardson, M., Haugland, R.A., 2005. Comparison of populations of mould species in homes in the UK and USA using mould specific quantitative PCR. Lett. Appl. Microbiol. 41, 367-373.

Wieslander, G., Norbäck, D., Nordström, K., Wålinder, R., Venge, P., 1999. Nasal and ocular symptoms, tear film stability, and biomarkers in nasal lavage, in relation to building dampness and building design in hospitals. Int. Arch. Occup. Environ. Health 72, 451-461.

Wieslander, G., Norbäck, D., Venge, P., 2007. Changes of symptoms, tear film stabiliity and eosinophilic cationic protein in nasal lavage fluid after re-exposure to a damp office building with a history of flooding. Indoor Air 17, 19-27.

Wieslander, G., Kumlin, A., Norbäck, D., 2010. Dampness and 2-ethyl-1-hexanol in floor construction of rehabilitation center: health effects in staff. Arch. Environ. Occup. Health 65, 3-11.

Wolkoff, P., Kärcher, T., Mayer, H., 2012. Problems of the outer eyes in the office environment- an ergophthalmologic approach. J. Occup. Environ. Med. 54, 621-631.

Please cite this article in press as: Norbäck, D., et al., Ocular symptoms and tear film break up time (BUT) among junior high school students in Penang, Malaysia - Associations with fungal DNA in school dust. Int. J. Hyg. Environ. Health (2017), http://dx.doi.org/10.1016/j.ijheh.2017.01.016 
Wolkoff, P., 2008. Healthy eye in office-like environments. Environ. Int. 34 , 1204-1214.

Wolkoff, P., 2010. Ocular discomfort by environmental and personal risk factors altering the precorneal tear film. Toxicol. Lett. 199, 203-212.

Wyon, N.M., Wyon, D.P., 1987. Measurement of acute response to draught in the eye. Acta Ophthalmol. (Copenh.) 65, 385-392.

Yoon, S.Y., Bae, S.H., Shin, Y.J., 2016. Low serum 25-hydroxyvitamin D levels are associated with dry eye syndrome. PLoS One 11, e0147847.
Zhang, X.,Zhao, Z., Nordqvist, T., Norback, D., 2011. A longitudinal study of sick building syndrome among pupils in relation to microbial components in dust in schools in China. Sci. Total Environ. 409, 5253-5259.

Zhao, Z., Sebastian, A., Larsson, L., Wang, Z., Zhang, Z., Norbäck, D., 2008. Asthmatic symptoms among pupils in relation to microbial dust exposure in schools in Taiyuan, China. Pediatr. Allergy Immunol. 19, 455-465.

Please cite this article in press as: Norbäck, D., et al., Ocular symptoms and tear film break up time (BUT) among junior high school students in Penang, Malaysia - Associations with fungal DNA in school dust. Int. J. Hyg. Environ. Health (2017), http://dx.doi.org/10.1016/j.ijheh.2017.01.016 